\title{
The role of cultivar susceptibility and vineyard age in GTD: examples from the Carpathian Basin
}

\author{
András Csótó ${ }^{1,3}$ - Péter Balling ${ }^{2}$ - Antal Nagy ${ }^{1}$ - Erzsébet Sándor ${ }^{1}$ \\ ${ }^{1}$ University of Debrecen, Faculty of Agricultural and Food Sciences and Environmental Management, Debrecen, Hungary \\ ${ }^{2}$ Research Institute for Viticulture and Oenology - Tokaj \\ ${ }^{3}$ Kerpely Kálmán Doctoral School, Debrecen, Hungary \\ csoto.andras@agr.unideb.hu
}

\begin{abstract}
SUMMARY
Grapevine trunk diseases (GTDs) are among the most severe problems in viticulture worldwide. The exact etiology and the role of endophytic microorganisms is not known yet and there is no adequate protection or curative treatment against the disease. Hungarian wine regions are also affected by the disease, and there is restricted information about the rate of infection nation-wide and about the susceptibility of the Hungarian cultivars.

The main objectives of our research are to measure the symptom expression and the damage caused by GTDs, to understand the epidemiology and etiology of the disease to establish a foundation of a proper disease management.

Cultivar susceptibility groups were created with the aim to allocate some Hungarian cultivars and the role of vineyard age was also examined in symptom expression.
\end{abstract}

Keywords: etiology, Botryosphaeria stevensii, esca, grapevine trunk diseases, symptom expression

\section{INTRODUCTION}

Nowadays, one of the most important problems in viticulture is the grapevine trunk diseases (hereinafter referred as GTDs), as there are no effective methods against them. The disease can cause necrosis either in a segment of shoots and arms or the whole trunk. Although annual percentage of decaying vines is low, economic aging of the vineyard (the point from when the vineyard is not profitable) will accelerate, because of the consecutive plant (Varga, 2009). 1.5 billion USD annual deficit of the sector was estimated by Hofstetter et al. (2012) worldwide, resulting from costs of replacing dead vines. This is a severe problem all across the European Union. GTD disease incidence was reported between $8 \%$ to $19 \%$ in Italy at 2014 , and circa $10 \%$ in Spain (Fontaine et al., 2016). In France 13\% of the vineyards are unproductive, resulting 1 billion EUR loss. The Hungarian wine regions are similarly affected. The ratio of the symptomatic plants was already over $12 \%$ in certain vineyards in 2007 (Dula, 2011). Between 2013 and 2015 disease incidence ranged from $0.17 \%$ to $42.11 \%$ at different vineyards in the Tokaj Wine Region, in Northeast-Hungary and presumably all Hungarian Wine Regions are affected with GTDs (Kovács et al., 2017).

The most important diseases globally among the GTDs are the 'sensu stricto' esca, eutypa dieback and botryosphaeria dieback, which are complex problems caused by different pathogens and environmental factors as well (Bertsch et al., 2012; Kovács and Sándor, 2016). According to Larignon and Dubos' (1997), the isolated pathogens can be different based on the part of the cross- section of the trunk or the cordon they originate from. Phaeoacremonium aleophilum and Phaemoniella chlamydospora, Phellinus punctatus, Stereum hirsutum were identified as the main causative fungal pathogens of esca, but Eutypa lata was also found in the brown decaying tissues. In Hungary, the most common GTD pathogen was the Diplodia seriata (Csótó et al., 2016; Kovács et al., 2014).

The uncertainty of pathogenicity and the role of several influencing environmental factors makes our image about GTDs even more abstract. Graniti et al. (2000) mentioned, that the pathogens could be present in the vineyards as part of the biocoenosis, without causing any symptoms. Extreme climatic conditions are decreasing the vigor of the vines, therefore the pathogens can proliferate in the woody tissue significantly. The survey of the disease can be difficult, because the infected vines does not show symptoms each year (Lecomte et al., 2011; Kovács et al., 2017).

The threat of early decline of grapevines has been documented since the antique times. The Latin word esca means tinder, comes from the usage of the spongy, dry, decayed wood tissue (Mugnai et al., 1999). Kövics (2009) originates the name from the greek word 'eskhatos', which means the last (stage of disease). At first, an anonymous author (1895) documented the symptom complex called "sunstroke" in California. Ravaz (1898) mentions the symptoms as „folletage” (cited in: Chiarappa, 2000).

Most GTDs can occur both in acute and chronic form. The acute symptoms result the rapid decaying of the arms or another woody parts of the vines. When the infected, decaying tissues are in the lower parts of the trunk, usually the whole plant dies suddenly. This symptom is called ,apoplexy”. Just before this stage, the shoots show significant alterations in photosynthetic activity (Letousey et al., 2010.) The tissues may show different changes in color and consistence depending on the pathogens present in the dissection of the apoplectic trunk (Larignon and Dubos, 1997). In case of Eutypa or Botryosphaeria dieback, although the woody tissues are brown and necrotic, but they remain intact (Moller et al., 1974; Hluchy et al., 
2007). Besides them, basidiomycetous fungi of esca complex cause white spongy rot in the inner tissues (Fischer, 2006) (Figure 1).

\section{Figure 1: Necrosis and white rot on the cross-section of a} decaying trunk (Photo: András Csótó)

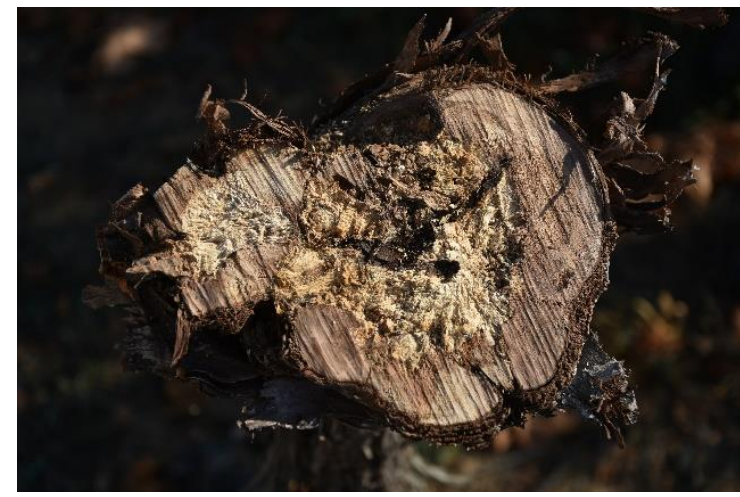

The foliar symptoms are very specific. The toxins produced by the pathogens in the trunk translocate to the leaves. This will cause color gradient interveinal striping, vernacularly the „tiger strip” (Haviland et al., 2019) (Figure 2).

The symptoms mentioned above mostly occur in older vineyards (Gubler et al., 2005). Grapevine trunk diseases can potentially affect young vines and freshly planted vineyards too, when it is called „black foot” or Petri-disease. Typical symptoms are stunted growth, weak sprouting or no sprouting at all, leaf chlorosis and marginal necrosis, dieback and decaying of the whole plant. These symptoms are commonly tied to the Phaeomoniella and Phaeoacremonium genera, likewise the esca complex (Gramaje and Armengol, 2011; Sidoti et al., 2000).

\section{Figure 2: Foliar symptoms on red grape cultivar} (Photo: András Csótó)

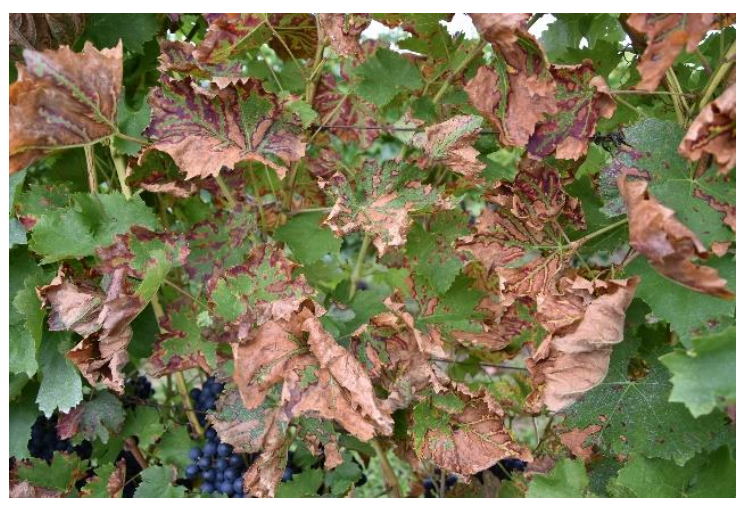

In the summer of 2019 a survey was carried out in the Carpathian-basin (Figure 3), in 7 wine regions involving nearly 20000 vines. Our aims were to get data about the susceptibility of cultivars and about the occurrence of the symptoms in the vineyards with different age.

Figure 3: Locations of the surveyed wine regions (Google Earth 2019)

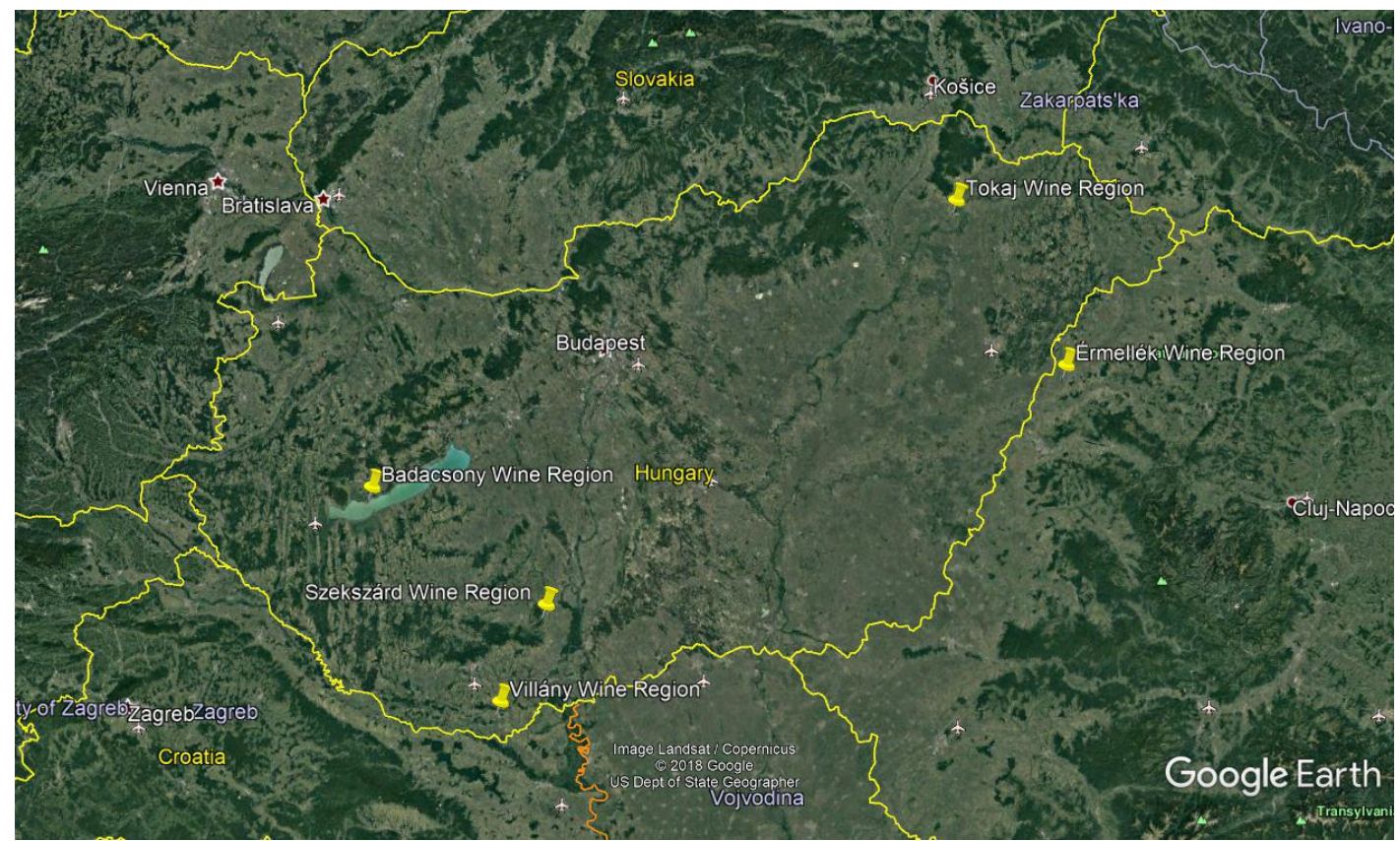




\section{MATERIALS AND METHODS}

The symptom expression of grapevine trunk diseases was measured in Hungary and certain bordering areas in the summer and early autumn of
2019. The survey was carried out in eight vineyards of five wine regions involving seventeen grapevine cultivars, of which ten were white and seven were red ones (Table 1).

Table 1

The surveyed vineyards and their cultivars. Cultivars sorted by decreasing number of studied parcels belonging to the given cultivar $\mathbf{R}=$ red cultivars, $\mathbf{W}=$ white cultivars

\begin{tabular}{|c|c|c|c|c|c|c|c|c|c|}
\hline & \multirow{2}{*}{$\begin{array}{c}\text { Wine region } \\
\text { Vineyard/ parcel }\end{array}$} & \multicolumn{2}{|c|}{ Érmellék (Romania) } & \multirow{2}{*}{$\begin{array}{c}\text { Tokaj } \\
\text { Szarvas }\end{array}$} & \multirow{2}{*}{$\begin{array}{c}\text { Badacsony } \\
\text { VWRI* }\end{array}$} & \multirow{2}{*}{$\begin{array}{c}\text { Szekszárd } \\
\text { Lajvér } \\
\text { Borbirtok }\end{array}$} & \multicolumn{3}{|c|}{ Villány } \\
\hline & & $\begin{array}{c}\text { Heit } \\
\text { Birtok }\end{array}$ & $\begin{array}{c}\text { Heit Papok } \\
\text { földje }\end{array}$ & & & & Bocor & Göntér & Zuhánya \\
\hline \multirow{17}{*}{$\underset{\Xi}{\stackrel{\Xi}{\Xi}}$} & Cabernet Franc ${ }^{\mathrm{R}}$ & & & & + & + & + & & + \\
\hline & Pinot Noir ${ }^{R}$ & & & & + & + & + & + & \\
\hline & Cabernet Sauvignon $^{\mathrm{R}}$ & & & & + & + & + & & \\
\hline & Olaszrizling ${ }^{\mathrm{w}}$ & & & & + & + & + & & \\
\hline & Kékfrankos ${ }^{\mathrm{R}}$ & & & & & + & + & & + \\
\hline & KirályleánykaW $^{\mathrm{W}}$ & + & & & + & & & & \\
\hline & Bakator $^{W}$ & + & + & & & & & & \\
\hline & Sauvignon Blanc ${ }^{\mathrm{W}}$ & & & & & + & & + & \\
\hline & Merlot $^{\mathrm{R}}$ & & & & & + & & + & \\
\hline & Chardonnay $^{\mathrm{w}}$ & & & & & + & & & \\
\hline & Cserszegi füszeres $^{\mathrm{W}}$ & & & & & + & & & \\
\hline & Kadarka $^{\mathrm{R}}$ & & + & & & & & & \\
\hline & Portugieser ${ }^{\mathrm{R}}$ & & & & & & & + & \\
\hline & Juhfark ${ }^{\mathrm{W}}$ & & & & + & & & & \\
\hline & Pinot Gris ${ }^{\mathrm{W}}$ & & & & + & & & & \\
\hline & Kéknyelü $^{\mathrm{W}}$ & & & & + & & & & \\
\hline & Hárslevelü ${ }^{\mathrm{W}}$ & & & + & & & & & \\
\hline
\end{tabular}

*National Agricultural Research and Innovation Centre Viticulture and Oenology Research Institute Badacsony

The surveyed areas were chosen to be representative for the climate and regional characteristics of the country. Tokaj and Érmellék Wine Regions belong to the continental precipitation regime, while the precipitation regime of Badacsony, Szekszárd and Villány Wine Regions are usually similar to the Mediterranean type (Borhidi, 1981). Despite these differences, the COUNCIL REGULATION (EC) No 479/2008 handles the whole area of Hungary in the $\mathrm{C} 1$ wine-growing zone. The studied vineyards were trained differently: mid-high single cordon was the most widespread, but the double Guyot and head training methods were represented too. The directional exposures, row directions of the vineyards were different as well as the inclination of the slopes.

In order to characterize the GTD infection in different vineyards (i) the relative frequency of the foliar symptom expression (hereinafter referred as $\mathrm{RF}_{\text {symptoms }}$ or symptom expression) was measured in 2019. Beyond that (ii) the relative frequency of the previously dead vines or hiatuses presumably caused by GTDs and the replacements were also studied and calculated. The sum of all values above (hereinafter referred as $\mathrm{RF}_{\text {damage }}$ ) reflected the damage caused by GTDs since the establishment of the vineyard.

Considering the effect of the age of the vineyard on the symptom expression, two age categories were used: young ( $<9$ year old) and mature (at least 9 year old) vineyards.

For statistical analysis IBM SPSS 23 software package was used. Comparisons were made with oneway ANOVA if data fits the assumptions of parametric tests. In this case Bonferroni post-hoc test was used. In other cases Kruskall-Wallis nonparametric test was carried out with Mann-Whitney U-test for post-hoc analysis (Ketskeméti et al., 2011).

\section{RESULTS AND DISCUSSION}

\section{Cultivar susceptibility groups}

Symptom expression was calculated from 200-400 studied plants per cultivars in each of the eight vineyards from five different wine regions in Hugary (Table 1). Both white and red cultivars were examined in every wine region, except Tokaj, where only indigenous white cultivar (Hárslevelü) was involved in the study. Most of the examined cultivars (Cabernet franc, Pinot noir, Cabernet sauvignon, Olaszrizling, Kékfrankos, Királyleányka, Bakator, Sauvignon blanc and Merlot) were studied in more than one vineyards, mainly at different wine regions.

There was a strong statistically significant correlation between the RF of symptom and the RF of damaged vines based on Pearson-correlation 
$(r=0.7053 ; p<0.05)$ therefore mainly the values of $\mathrm{RF}_{\text {symptoms }}$ were used in further analysis.

Mean symptom expression varied between less than $0.5 \%$ (Bakator: $0.12 \%$ and Chardonay: $0.25 \%$ ) and more than $10 \%$ (Kadarka: $11.43 \%$ and Kéknyelü: $19.88 \%$ ). It must be mentioned that both of the studied Bakator was in the younger age group, and Kadarka was surveyed only in one vineyard belonging to the older age group. Therefore the susceptibility determination of these cultivars need further study. Based on the mean symptom expression $\left(\mathrm{RF}_{\text {symptoms }}\right)$ in 2019, susceptibility groups were created to acquire information about the susceptibility of the different cultivars. Three susceptibility groups could be separated, based on larger steps of increasing symptom expression values. There was significant difference between the main symptom expression values of these groups. The symptom expressions of the slightly $\left(\mathrm{RF}_{\text {symptoms }}\right.$ : $\left.0.52 \% \pm 0.35\right)$ and the highly susceptible ( $\mathrm{RF}_{\text {symptoms: }}$ 9.82\% \pm 4.78 ) groups were differed statistically, although the transitional moderately susceptible ( $\mathrm{RF}_{\text {symptoms }}$ : $3.42 \% \pm 1.09$ ) group did not show clear separation from them (Table 2). When four groups formed based on their symptom expression (different by quartiles), they could not be separated clearly based on their susceptibility values either. Only the slightly susceptible group $\left(\mathrm{RF}_{\text {symptoms }}: 0.52 \% \pm 0.35\right)$ showed significant differences from the two most sensitive groups (Susceptible with $\mathrm{RF}_{\text {symptoms }}$ : $3.09 \%$ \pm 0.92 , and Highly susceptible with $\mathrm{RF}_{\text {symptoms }}$ : $6.36 \%$ \pm 1.54 ) (Table 2).

The sequence of susceptibility coincide broadly with the previous, international data. The symptom expression was less frequent in Merlot, Pinot noir and Chardonnay than in Sauvignon blanc, Cabernet sauvignon and Cabernet franc plantations (Edwards et al,. 2007; Feliciano et al., 2004; Lorraine et al., 2012; Ramírez et al., 2018). Similarly Chardonnay, Merlot and Pinot noir were in the slightly or moderately susceptible groups, while Sauvignon blanc, Cabernet sauvignon and Cabernet franc in the Susceptible and Highly susceptible groups (Table 2). The following Hungarian cultivars were slightly susceptible (similarly to the Chardonnay): Bakator, Cserszegi füszeres and Kékfrankos. However Juhfark, Hárslevelü, Kadarka and Kéknyelü were highly susceptible in our survey, similarly to Cabernet sauvignon. These susceptibilities are showing good coincidence with earlier surveys (in Hungary) of our working group too (Csótó et al., 2016).

Mean symptom expression of cultivars and susceptibility groups (with mean values \pm SD) of the different cultivars by major steps of the symptom expression values and quartiles of them. Differences of mean symptom expression (\%) of groups were evaluated by Kruskall-Wallis test and Mann-Whitney U-test. Letters sign significant differences based on U-test

\begin{tabular}{cccc}
\hline Cultivar & $\begin{array}{c}\text { Mean symptom- } \\
\text { expression }(\%)\end{array}$ & $\begin{array}{c}\text { Susceptibility groups by } \\
\text { major steps }\end{array}$ & $\begin{array}{c}\text { Susceptibility groups by } \\
\text { quartiles }\end{array}$ \\
\hline Bakator & 0.12 & & \\
Chardonnay & 0.25 & Slightly susceptible & Slightly susceptible \\
Cserszegi füszeres & 0.50 & $0.52( \pm 0.35) \mathrm{a}$ & $0.52( \pm 0.35) \mathrm{a}$ \\
Merlot & 0.75 & & \\
Kékfrankos & 0.96 & & Moderately susceptible \\
Sauvignon Blanc & 2.00 & $3.42( \pm 1.09) \mathrm{ab}$ & $3.09( \pm 0.92) \mathrm{ab}$ \\
Pinot Noir & 2.65 & & \\
Királyleanyka & 3.83 & & Susceptible \\
Pinot Gris & 3.86 & & $6.36( \pm 1.54) \mathrm{b}$ \\
Portugieser & 4.75 & Highly susceptible & \\
Cabernet Franc & 5.34 & $9.82( \pm 4.78) \mathrm{b}$ & Highly susceptible \\
Olaszrizling & 7.60 & & $12.01( \pm 5.44) \mathrm{b}$ \\
Juhfark & 7.76 & & \\
Cabernet Sauvignon & 8.15 & & $\mathrm{H}=19.576, \mathrm{p}=0.0002$ \\
Hárslevelü & 8.59 & $\mathrm{H}=18.7281, \mathrm{p}=0.0001$ & \\
Kadarka & 11.43 & & \\
Kéknyelü & 19.88 & &
\end{tabular}

\section{Effect of the vineyard age to the relative frequency of symptom expression}

Besides the cultivar susceptibility, the vineyard age was an important factor in symptom expression. The relative frequency of foliar symptom expression in case of older vineyards was significantly higher than the younger ones regardless of the effect of the cultivars and other edaphic conditions. The vineyard parcels were separated to two age groups: less, than 9 year old and at least 9 year old (Table 3). While the difference was only marginally significant (at $p<0.1$ level) in the relative frequency of damaged vines between the age groups (Figure 4). These outcomes confirmed results of Díaz and Latorre (2013) and Úrbez-Torres et al. (2008) who found that in mature vineyards (older than 7-8 years) the symptoms occur more likely. 
The surveyed vineyard parcels by age group

\begin{tabular}{|c|c|c|c|c|c|}
\hline \multicolumn{6}{|c|}{ All surveyed vineyard parcels } \\
\hline \multicolumn{3}{|c|}{ Less than 9 years old } & \multicolumn{3}{|c|}{ More than 9 years old } \\
\hline Wine region & Parcel & Cultivar & Wine region & Parcel & Cultivar \\
\hline Érmellék & Heit Papok földje & Kadarka & Badacsony & VWRI & Cabernet sauvignon \\
\hline Érmellék & Heit Papok földje & Bakator & Badacsony & VWRI & Cabernet franc \\
\hline Villány & Zuhánya & Cabernet sauvignon & Villány & Göntér & Merlot \\
\hline Villány & Zuhánya & Kékfrankos & Villány & Göntér & Portugieser \\
\hline Villány & Zuhánya & Cabernet franc & Villány & Göntér & Pinot noir \\
\hline Érmellék & Heit Birtok & Bakator & Villány & Göntér & Sauvignon blanc \\
\hline Szekszárd & Lajvér Birtok & Chardonnay & Badacsony & VWRI & Kiralyleányka \\
\hline Szekszárd & Lajvér Birtok & Kekfrankos & Tokaj & Szarvas & Harslevelu \\
\hline Szekszárd & Lajvér Birtok & Cabernet franc & Badacsony & VWRI & Pinot noir \\
\hline Szekszárd & Lajvér Birtok & Cabernet sauvignon & Badacsony & VWRI & Juhfark \\
\hline Szekszárd & Lajvér Birtok & Cserszegi füszeres & Badacsony & VWRI & Juhfark \\
\hline Szekszárd & Lajvér Birtok & Pinot noir & Badacsony & VWRI & Juhfark \\
\hline Szekszárd & Lajvér Birtok & Sauvignon Blanc & Badacsony & VWRI & Szürkebarát \\
\hline Szekszárd & Lajvér Birtok & Olaszrizling & Badacsony & VWRI & Szzürkebarát \\
\hline \multirow[t]{9}{*}{ Szekszárd } & Lajvér Birtok & Merlot & Badacsony & VWRI & Keknyelü \\
\hline & & & Badacsony & VWRI & Keknyelü \\
\hline & & & Badacsony & VWRI & Olaszrizling \\
\hline & & & Villány & Bocor & Kékfrankos \\
\hline & & & Villány & Bocor & Pinot noir \\
\hline & & & Villány & Bocor & Cabernet sauvignon \\
\hline & & & Villány & Bocor & Olaszrizling \\
\hline & & & Villány & Bocor & Cabernet franc \\
\hline & & & Érmellék & Heit Birtok & Kiralyleányka \\
\hline
\end{tabular}

*National Agricultural Research and Innovation Centre Viticulture and Oenology Research Institute Badacsony

Figure 4: Symptom expression and ratio of damaged vines by age categories. Signs show significant differences at $\mathbf{p}<0,1(+)$ and $\mathbf{p}<0,01(* *)$ levels based on Bonferroni test

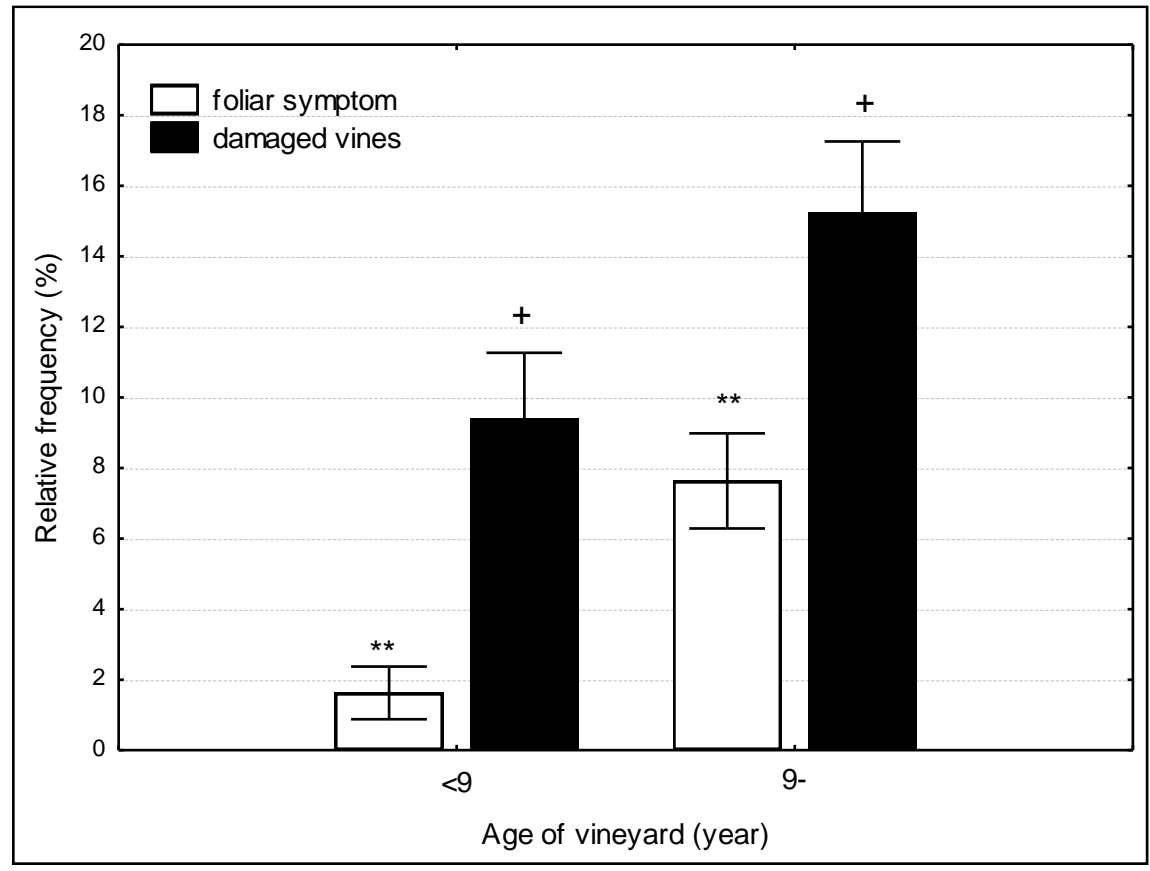

The survey will be carried on in these vineyards in the following years, so the relation between symptom expression and its effecting ecological factors may be determined too, like climatic and water stress (Andreini 
et al., 2014; Songy et al., 2019; Sosnowski et al., 2016; Van Niekerk et al., 2011), rootstock type (Andreini et al., 2014) or the composition of endophytic microorganisms (Gramaje et al., 2015; Del Frari et al., 2019).

\section{CONCLUSIONS}

Strong correlation was found between the relative frequency of retrospectively and currently damaged vines and the relative frequency of symptom expression. Cultivar susceptibility groups we created based on the latter, because of its higher accuracy. The international Merlot, Pinot Noir, Chardonnay, as well as the indigenous Bakator, Cserszegi füszeres and Kékfrankos cultivars proved to be less susceptible. On the other hand Sauvignon Blanc, Cabernet Sauvignon, Cabernet Franc widespread cultivars, as well as the Juhfark, Hárslevelü, Kadarka and Kéknyelü tipically grown in the Carpathian basin were more sensitive to the grapevine trunk diseases (GTD). These results may help the winegrowers to choose less susceptible cultivars in case other factors (e.g water stress) may prone the GTD symptom expression to reduce economic loss.
Based on previous results, two age groups were created to separate younger (at the eighth year) and older ("mature") cultivars. In accordance with previous statements (Díaz and Latorre, 2013; Kovács et al., 2017; Úrbez-Torres et al., 2008), we also found, that the relative frequency of foliar symptom expression was significantly lower in the younger vineyards. Whether it is due to the lower frequency of infection with GTD pathogen(s), the differences in the endophytic microbial composition and ratio or the difference in the plant resistance, needs further studies.

\section{ACKNOWLEDGEMENTS}

We would like to send thanks to the winegrowers, wineries and institutes for consulting and granting us the vineyards to survey: Attila Nagy (Villány), Heit Winery (Diosig), Lajvér Winery (Szálka), Research Institute for Viticulture and Oenology - Tokaj and National Agricultural Research and Innovation Centre - Research Institute for Viticulture and Oenology Badacsony.

\section{REFERENCES}

Andreini, L.-Cardelli, R.-Bartolini，S.-Scalabrelli, G.-Viti, R. (2014): Esca symptoms appearance in Vitis vinifera $\mathrm{L}$.: influence of climate, pedo-climatic conditions and rootstock/cultivar combination. Vitis, 53(1), 33-38.

Anonymous (1985): Sunstroke of the vine. Bulletin University of California, Berkeley, CA, USA, 450-451.

Bertsch, C.-Ramírez-Suero, M.-Magnin-Robert, M.-Larignon, P.Chong, J.-Abou-Mansour, E.-Spagnolo, A.-Clément, C.Fontaine, F. (2012): Grapevine trunk diseases: complex and still poorly understood. Plant Pathology 62. (2) 243-265. https://bsppjournals.onlinelibrary.wiley.com/doi/epdf/10.1111/j 1365-3059.2012.02674.x Doi: $\quad$ 10.1111/j.13653059.2012.02674.x

Borhidi, A. (1981): Az éghajlat in: Hortobágyi, T.-Simon, T. (editors): Növényföldrajz, társulástan és ökológia. Tankönyvkiadó, Budapest. ISBN: 963-17-5559-2. 352-372.pp

Chiarappa, L. (2000): Esca (black measles) of grapevine. An overview. Phytopathologia Mediterranea 39. 11-15. file://C:/Users/Asus/Downloads/4785-Article\%20Text-4713-11-20190716.pdf

Csótó, A.-Kovács, Cs.-Rakonczás, N.-Sándor, E. (2016): Survey and examination of GTDs and isolation of pathogens in the grapevine variety collection of the University of Debrecen In: Monika, Wesołowska (szerk.) Meeting of Young Researchers from V4 Countries Abstract book University of Rzeszów, pp. 20-20. 1 . https://drive.google.com/file/d/0B9wjgUhkhq6vNjJBaVgwZXJ QTGM/view?pref=2\&pli=1

Del Frari, G.-Gobbi, A.-Aggerbeck, M.R.-Oliveira, H.-Hansen, L.H.Ferreira, R.B. (2019): Characterization of the Wood Mycobiome of Vitis vinifera in a Vineyard Affected by Esca. Spatial Distribution of Fungal Communities and Their Putative Relation with Leaf Symptoms. Frontiers in Plant Science 10. 910. https://www.frontiersin.org/article/10.3389/fpls.2019.00910

Díaz, G.A.-Latorre, B.A. (2013): Efficacy of paste and liquid fungicide formulations to protect pruning wounds against pathogens associated with grapevine trunk diseases in Chile. Crop Protection, 46, 106-112. https://www.sciencedirect.com/science/article/pii/S0261219413 000070?via\%3Dihub https://doi.org/10.1016/j.cropro.2013.01.001

Dula, B. (Mrs.) (2011): Korai szőlőtőke-pusztulást okozó szaporító anyaggal terjedő kórokozó gombák (Propagation material borne fungus pathogens causing early stock decay in vineyards). Növényvédelem 47. (11) 461-463.

Edwards, J.-Salib, S.-Thomson, F.-Pascoe, I.G. (2007): The impact of Phaeomoniella chlamydospora infection on the grapevine's physiological response to water stress part 2: Cabernet Sauvignon and Chardonnay. Phytopathologia Mediterranea, 46, 38-49. https://www.jstor.org/stable/26463269?seq=1

Feliciano, A.-Eskalen, A.-Gubler, W. (2004): Differential susceptibility of three grapevine cultivars to Phaeoacremonium aleophilum and Phaeomoniella chlamydospora in California. Phytopathologia Mediterranea, 43, 66-69. https://www.jstor.org/stable/26456687?seq=1

Fischer, M. (2006): Biodiversity and Geographic Distribution of Basidiomycetes Causing Esca-Associates White Rot in Grapevine: A Worldwide Perspective. Phytopathologia Mediterranea 45(4): 30-42 https://www.jstor.org/stable/26463234?seq=1

Fontaine, F.-Gramaje, D.-Armengol, J.-Smart, R.-Nagy, Z.A.Borgo, M.-Rego, C.-Corio-Costet, M.F. (2016): Grapevine Trunk Diseases. A review. COIV publications, $1^{\text {st }}$ Edition Paris. 
http://www.oiv.int/public/medias/4650/trunk-diseases-oiv2016.pdf

Graniti, A.-Surico, G.-Mugnai, L. (2000): Esca of grapevine: a disease complex or a complex of diseases? Phytopathologia Mediterranea 39, 16-20. https://www.jstor.org/stable/26456520?seq=1

Gramaje, D.-Armengol, J. (2011): Fungal trunk pathogens in the grapevine propagation process: potential inoculum sources, detection, identification, and management strategies. $\begin{array}{llll}\text { Plant disease } & 95 & \text { (9) 1040-1055. }\end{array}$ https://apsjournals.apsnet.org/doi/10.1094/PDIS-01-11-0025

Gramaje, D.-Mostert, L.-Groenewald, J.Z.-Crous, P. (2015): Phaeoacremonium: From esca disease to phaeohyphomycosis. Fungal Biology, 119-9, pp. 759-783.

Gubler, W.D. - Rolshausen, P.E.-Trouillase, F.P.-Urbez, J.R.Voegel, T.-Leavitt, G.M.-Weber, E.A. (2005): Grapevine trunk diseases in California. Practical Winery and Vineyard p.9.

Haviland, D.R.-Bettiga, L.J.-Varela, L.G.-Baldwin, R.A.Roncoroni, J.A.-Smith, R.J.-Westerdahl, B.B.-Bentley, W.J.Daane, K.M.-Ferris, H.-Gubler, W.D.-Hembree, K.J.-Ingels, C.A.-Zalom, F.G.-Zasada, I. (2019): UC IPM Pest Management Guidelines Grape. UC ANR Publication 3448. http://ipm.ucanr.edu/PDF/PMG/pmggrape.pdf

Hluchy, M.-Ackermann, P.-Zacharda, M.-Lastuvka, Z.-Bagar, M.Jetmarová, E.-Vanek，G.-Szőke， L.-Plísek， B. (2007): A gyümölcsfák és a szőlő betegségei és kártevői. Biocont Laboratory Ltd. p. 266.

Ketskeméti, L.-Izsó, L.-Könyves, T.E. (2011): Bevezetés az IBM SPSS Statistics programrendszerbe. Artéria Stúdió Kft. Budapest pp. 579.

Kovács, Cs.-Peles, F.-Xie, H.-Szojka, A.-Hajdu, G.-Bihari, Z.Sándor, E. (2014): Isolation and identificationof endophytic fungi connected to Grapevine Diseases, from the Tokaj wine rwgion, Hungary. Agrártudományi Körlemények/Acta Agraria Debreceniensis: 56 61-66. pp. Paper: ISSN 1587-1282, 6 p. http://www.agr.unideb.hu/acta/pub/189/isolation-andidentification-of-endophytic-fungi-connected-to-grapevinediseases-from-the-tokaj-wine-region-hungary/

Kovács, Cs.-Balling, P.-Bihari, Z.-Nagy, A.-Sándor, E. (2017): Incidence of grapevine trunk diseases is influenced by soil, topology and vineyard age, but not by Diplodia seriata infection rate in the Tokaj Wine Region, Hungary. Phytoparasitica 45: 1 pp. 21-32.

Kovács, Cs.-Sándor, E. (2016): The increasing importance of grapevine trunk diseases International Journal of Horticultural Science 3-4 pp. 21-30. Paper: ISSN 1585-0404, 10 p. https://ojs.lib.unideb.hu/IJHS/article/view/1188/1186

Kövics, G. (2009): Növénykórtani vademecum. NOFKA kiadása, 470. pp. ISBN: 978-963-88096-0-5

Larignon, P.-Dubos, B. (1997): Fungi associated with esca disease in grapevine. European Journal of Plant Pathology 103. 147-157. https://link.springer.com/content/pdf/10.1023\%2FA\%3A10086 38409410.pdf

Lecomte, P.-Darrieutort, G.-Laveau, C.-Blancard, D.-Louvet, G.Goutouly, J.-P.-Rey, P.-Guérin-Dubrana, L. (2011): Impact of biotic and abiotic factors on the development of Esca decline disease Integrated protection and production in viticulture IOBC/ wprs Bulletin Vol. 67, 2011 pp. 171-180 file:///C:/Users/Asus/Downloads/2011-ACT\%235_+LecomteIOBC\%20(1).pdf
Letousey, P.-Baillieul, F.-Perrot, G.-Rabenoelina, F.-Boulay, M.Vaillant-Gaveau, N.-Clément, C.-Fontaine, F. (2010): Early Events Prior to Visual Symptoms in the Apoplectic Form of Grapevine Esca Disease. Phytopathology 100(5):424-31 https://apsjournals.apsnet.org/doi/pdf/10.1094/PHYTO-100-50424

Lorraine, B.-Ky, I.-Pasquier, G.-Jourdes, M.-Dubrana, L.G.-Geny, L.-Rey, P.-Donéche, B.-Tiessedre, P.L. (2012): Effect of Esca disease on the phenolic and sensory attributes of Cabernet Sauvignon grapes, musts and wines. Australian Journal of Grape and Wine Research, 18(1), 64-72 https://onlinelibrary.wiley.com/doi/full/10.1111/j.17550238.2011.00172.x

Mugnai, L.-Graniti, A.-Surico, G. (1999): Esca (Black Measles) and Brown Wood-Streaking: Two Old and Elusive Diseases of Grapevines. Plant Disease 83(5):404-418 https://doi.org/10.1094/PDIS.1999.83.5.404

Moller, W.J.-Kasimatis, A.N.-Kissler, J.J. (1974): A dying arm disease of grape in California. Plant Disease Reporter 58, 86971.

Ramírez, M.-Perez, L.M.-Montealegre, J.R. (2018): Susceptibility of different grapevine (Vitis vinifera L.) cultivars to Diplodia seriata and Diplodia mutila. Ciencia e Investigación Agraria 45 (1) https://scielo.conicyt.cl/scielo.php?script=sci_arttext\&pid=S07 18-16202018000100093\&lng=en\&nrm=iso\&tlng=en

Ravaz, L. (1898): Sur le folletage. Revue de Viticulture, 10, 184-186. Sidoti, A.-Buonocore, E.-Serges, T.-Mugnai, L. (2000): Decline of young grapevines associated with Phaeoacremonium $\begin{array}{llll}\text { chlamydosporum } & \text { in }\end{array}$ Phytopathologica Mediterranea 39, 87-91. https://www.jstor.org/stable/26456532?seq=1

Songy, A.-Fernandez, O.-Clément, C.-Larignon, P.-Fontaine, F. (2019): Grapevine trunk diseases under thermal and water stresses. Planta, 249(6), 1655-1679.

Sosnowski, M.-Ayres, M.-Scott, E. (2016): Trunk diseases: the influence of water deficit on grapevine trunk disease. Wine \& Viticulture Journal, 31(4), 46.

Úrbez-Torres, J.R.-Leavitt, G.M.-Guerrero, J.C.-Guevara J.Gubler, W.D. (2008): Identification and Pathogenicity of Lasiodiplodia theobromae and Diplodia seriata, the Causal Agents of Bot Canker Disease of Grapevines in Mexico. Plant Disease 92 (4) 519-529. pp. https://doi.org/10.1094/PDIS-92-40519

Van Niekerk, J. M.-Bester, W.-Halleen, F.-Crous, P.W.-Fourie, P.H. (2011): The distribution and symptomatology of grapevine trunk disease pathogens are influenced by climate. Phytopathologia Mediterranea, 50, S98-S111.

Varga, Z. (2009): Vitis fajok és fajták tőkepusztulásának összehasonlító vizsgálata és a védekezés lehetőségei. Doktori disszertáció, Pannon Egyetem Georgikon Kar, Keszthely, Növénytermesztési és Kertészeti Tudományok doktori iskola http://docplayer.hu/4136625-Pannon-egyetem-georgikon-karkeszthely.html 
